\title{
Detection of Formalin in Fish Samples Collected from Dhaka City, Bangladesh
}

*Riaz Uddin, Moin Ibna Wahid, Tasbira Jesmeen, Naz Hasan Huda, Kumar Bishwajit Sutradhar Department of Pharmacy, Stamford University Bangladesh, 51, Siddeswari Road, Dhaka-1217, Bangladesh.

Original Research Article

\begin{abstract}
Fish is an important food stuff and source of protein all over the world. In Bangladesh fisheries sector contributes a lot in case of earning foreign currency and meeting domestic need of animal protein. To meet the domestic need Bangladesh imports fish and fish products from neighboring countries. But it is evident from several studies that fish items in Bangladesh contain formalin which is a highly hazardous and carcinogenic chemical. An attempt was taken to detect the extent of formalin use in fish available in Dhaka city. From five different local markets five species of fishes were collected and presence of formalin was detected using the "formalin detection kit in fish" developed by Bangladesh Council of Scientific and Industrial Research (BCSIR). The study indicates that $70 \%$ Rui fish is formalin contaminated and almost $50 \%$ of fish samples contain formalin.
\end{abstract}

Key words: Formaldehyde, BCSIR, Formalin detection kit, Carcinogen, Fisheries, Livestock.

\section{INTRODUCTION}

The role of fisheries and livestock sectors in the development of agro-based economy of Bangladesh is very important and promising. They contribute around $8 \%$ to national income, which also is $32 \%$ of the total agricultural income. About $90 \%$ of animal protein in our diet comes from fish and livestock (MoFL, 2011). The fisheries sector contributes $5.10 \%$, of the country's export earnings, $4.91 \%$ of its GDP and provides $63 \%$ of the national animal protein consumption. Fish and fishery products are the country's third largest export commodity contributing $5.10 \%$ of its exchange earnings, in 2002-2003 Bangladesh earned US\$ 324 million of which shrimp alone contributed $72 \%$ of the total by quantity and $89 \%$ by value (FAO, 2011). It is claimed that the total fish production has

\section{*Corresponding Author}

Riaz Uddin

Lecturer, Department of Pharmacy

Stamford University Bangladesh

51, Siddeswari Road

Dhaka-1217, Bangladesh

E-mail: kp_ruddin@yahoo.com

Contact No.: +8801749995653 increased significantly over the last few decades (DoF, 2009) but it is not sufficient to meet up the growing demand of the country (Yeasmin et al., 2010a). As a result imported fishes from neighboring countries enter in the domestic market and it was reported that more than 80 metric ton of fish and fishery products enter into Bangladesh every day through the Teknaf border from Myanmar (Kibria, 2007). Available reports suggest that formalin is sometimes added or sprayed to the fishes by the fish traders while transporting to domestic marketing chain to prevent spoilage and increase shelf life (Yeasmin et al., 2010a). Studies conducted at different markets in Dhaka city (Hossain et al., 2008; Haque and Mohsin, 2009) and Mymensingh Sadar (Yeasmin et al., 2010a) rationalizes the incidence of adding formaldehyde/formalin to fishes especially imported from neighboring countries.

Formaldehyde is the simplest member of aldehyde family but a very reactive chemical, where the gaseous form is known as formaldehyde and the liquid form as formalin 
(Noordiana et al., 2011). Formalin is a solution of $37 \%(\mathrm{w} / \mathrm{w})$ of formaldehyde $(\mathrm{H}-\mathrm{CHO})$ in water which is used as a preservative in medical laboratories, as an embalm fluid and as a sterilizer. Formalin is also used in treatment against fish diseases caused by protozoa and fungi. Food and Drug Administration of the United States approved formalin for use in aquaculture as parasiticides and fungicides. It is, however, not approved for usage in aquaculture in Europe and Japan because of its association with cancer and tumor development. Use of formalin in food for human consumption is also banned in Bangladesh (Yeasmin et al., 2010b). Recently, International Agency for Research on Cancer (IARC, 2004) has classified formaldehyde as a Group 1 carcinogenic to humans. According to the United States Environmental Protection Agency (EPA), maximum daily dose reference (RfD) for formaldehyde is $0.2 \mu \mathrm{g} / \mathrm{g}$ body weight per day (Wang et al., 2007; Noordiana et al., 2011). Even those who spray or inject formalin over a long period of time will likely suffer health complications such as blindness, asthma and even lung cancer (Hossain, 2011).

\section{MATERIALS AND METHODS}

\section{Fish sample collection}

Fish samples were collected from different markets in Dhaka city. The markets include Jatrabari Bazar, Karwan Bazar, and different super shops at Dhanmondi, Maghbazar and Kazipara. Fish samples include Rui (Labeo rohita), Catla (Catla catla), Mrigal (Cirrhina mrigala), Ilish (Hilsa ilisa) and Sarputi (Puntius sarana).

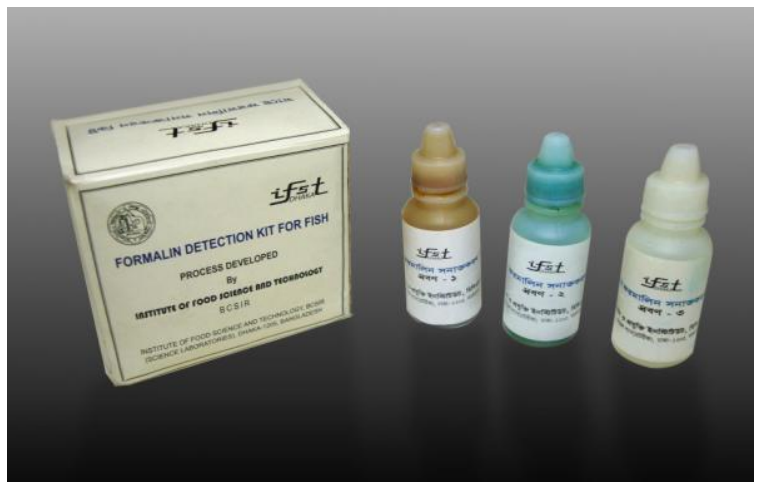

Figure 1. Formalin Detection Kit for Fish ${ }^{\circledR}$ developed by BCSIR.
Table 1. Distribution of fishes being tested.

\begin{tabular}{llc}
\hline Fish Market & \multicolumn{1}{c}{ Fish Species } & $\begin{array}{c}\text { Quantity } \\
\text { Tested } \\
\text { (pcs.) }\end{array}$ \\
\hline Jatrabari Bazar & Rui (Labeo rohita) & 4 \\
& Catla (Catla catla) & 4 \\
& Mrigal (Cirrhina mrigala) & 4 \\
& Ilish (Hilsa ilisa) & 4 \\
& Sharputi (Puntius sarana) & 4 \\
\hline Kawran Bazar & Rui (Labeo rohita) & 4 \\
& Catla (Catla catla) & 4 \\
& Mrigal (Cirrhina mrigala) & 4 \\
& Ilish (Hilsa ilisa) & 4 \\
& Sharputi (Puntius sarana) & 4 \\
\hline Super Shop, & Rui (Labeo rohita) & 4 \\
Dhanmondi & Catla (Catla catla) & 4 \\
& Mrigal (Cirrhina mrigala) & 4 \\
& Ilish (Hilsa ilisa) & 4 \\
& Sharputi (Puntius sarana) & 4 \\
\hline Super Shop, & Rui (Labeo rohita) & 4 \\
Moghbazar & Catla (Catla catla) & 4 \\
& Mrigal (Cirrhina mrigala) & 4 \\
& Ilish (Hilsa ilisa) & 4 \\
& Sharputi (Puntius sarana) & 4 \\
\hline \multirow{5}{*}{ Kara Shop, } & Rui (Labeo rohita) & 4 \\
& Catla (Catla catla) & 4 \\
& Mrigal (Cirrhina mrigala) & 4 \\
& Ilish (Hilsa ilisa) & 4 \\
& Sharputi (Puntius sarana) & 4 \\
\hline & & $\mathbf{1 0 0}$ \\
\hline
\end{tabular}

Qualitative detection of formalin using Formalin Detection Kit for Fish ${ }^{\circledR}$

Qualitative detection of formalin was performed by the formalin detection kit for fish ${ }^{\circledR}$ developed by Bangladesh Council of Scientific and Industrial Research (BCSIR). This kit contains three different solutions labeled as solution 1,2 and 3. First, the samples (cut fish parts) were washed with small quantity of water and a portion of washed out water was taken in a test tube using a dropper incorporated in the kit. 15 drops of solution 1 was added in the test-tube containing washed out water. After well stirring, the solution was allowed react for 30 second. 15 drops of solution 2 was added in the same test-tube. After waiting for 30 seconds, solution 3 was added, change in color pink or red indicated the presence of formalin whereas unchanged color indicated the sample is free from formalin. 


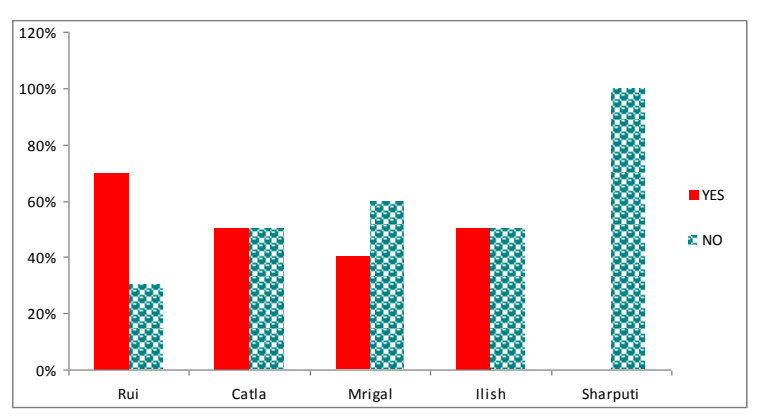

Figure 2. Fish species-wise presence of formalin.

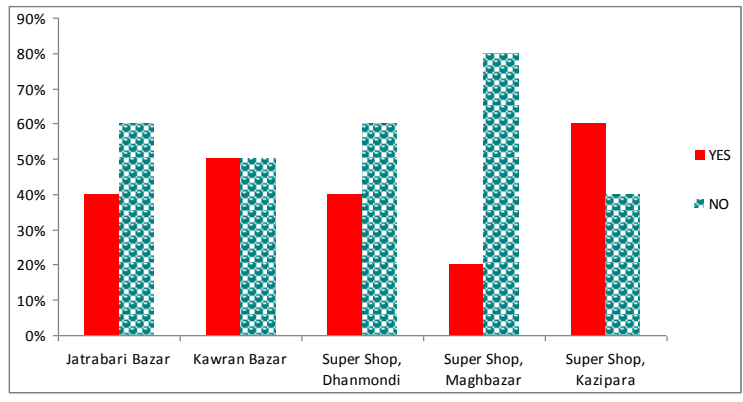

Figure 3. Market wise presence of formalin in fish samples.

a long time. But as it is a carcinogenic chemical and has got the ability to produce serious health hazards like cancers of the lung, nasopharynx, oropharynx and nasal passage to the population regulatory bodies should take necessary steps to minimize and stop formalin treatment of the fish. The current study involves a small number of samples to detect formalin in fish in local market in Dhaka city. But it gives us a comprehensive picture to understand the extent and magnitude of the scenario. interagency program of the Department of Health and Human Services, named formaldehyde as a known human carcinogen in its $12^{\text {th }}$ Report on Carcinogens (National Toxicology Program, 2011). Though it is harmful and potential source of health hazard to human some fish traders are engaged in treating fish with formalin.

It was observed in a study conducted in Dhaka city (Haque and Mohsin, 2009) that almost 5\% shops of total consumable fishes contain formalin treated fishes those are sold in fish markets. They found this intensity to vary market to market and species to species. They found that Rui fish was highly affected by formalin whereas Karwan Bazar represented highest number of formalin treated fish. In this current study mainly big fish species were investigated which indicated a high percentage of presence of formalin in fish.

\section{CONCLUSION}

It is assumed that formalin is added to the fish, especially those come from bordering countries by the local fish traders to keep the fish fresh for

\section{REFERENCES}

DoF, 2009. Department of Fisheries. Fish fortnight publication, 2009. Published by the Department of Fisheries, Ministry of Fisheries \& Livestock, Government of the People's Republic of Bangladesh.

FAO, 2011. FAO Country sector fact sheets placeholder. National Aquaculture Sector Overview: Bangladesh.

http://www.fao.org/fishery/countrysector/naso_ba ngladesh/en [Accessed on May 31, 2011]

Haque E and Mohsin ABM. 2009. Intensity of formalin use for consumable fish preservation in Dhaka city, Bangladesh. J. Fish. Int. 4(3): 51-53.

Hossain MM. 2011. Consumption in Rural Bangladesh: Households, Lifestyles, and Identities. Academic Dissertation presented to Consumer Economics Unit, Department of Economics and Management, University of Helsinki, Finland.

Hossain MS, Rahman MA, Sharkar TK, Shahjalal HM. 2008. Formaldehyde content in the Rui Fish (Labeo rohita) in Bangladesh and effect of formaldehyde on lipid peroxidation in rat liver and intestinal tissues. J. Med. Sci. 8(4): 405-409.

International Agency for Research on Cancer. 2004. Monographs on the Evaluation of Carcinogenic 
Risks to Humans, Vol. 88, International Agency for Research on Cancer, Lyon, France.

Kibria G. 2007. Formalin and Fish Trade in Bangladesh Human and Environmental Risks. News article retrieved from http://www.sydneybashibangla.com [Accessed on May 31, 2011]

MoFL, 2011. Ministry of Fisheries \& Livestock, Government of the People's Republic of Bangladesh http://www.mofl.gov.bd/ [Accessed on May 31, 2011]

National Toxicology Program (June 2011). Report on Carcinogens, Twelfth Edition. Department of Health and Human Services, Public Health Service, National Toxicology Program. [Accessed on July 05, 2011].

$\mathrm{Ng}$, C.S. Determination of formaldehyde in fish meat using Nash's reagent. Hasegawa, H. (Ed.). Laboratory Manual on Analytical Methods and Procedures for Fish and Fish Products. Marine Fisheries Research Dept., Southeast Asian Fisheries Development Center, Singapore. 1987. B.5. 1-5.4.

Noordiana, N, Fatimah, AB and Farhana, YCB. 2011. Formaldehyde content and quality characteristics of selected fish and seafood from wet markets. International Food Research Journal 18: 125-136.

Tunhun D, Kanont S, Chaiyawat M and Raksakulthai N. 1996. Detection of Illegal Addition of Formaldehyde to Fresh Fish. ASEAN Food Journal. 11(2):74-77.

Yeasmin T, Reza MS, Khan MNA, Shikha FH, Kamal M. 2010a. Present status of marketing of formalin treated fishes in domestic markets at Mymensingh district in Bangladesh. Int. J. BioRes. 1(4): 21-24.

Yeasmin T, Reza MS, Shikha FH, Khan MNA, Kamal M. 2010b. Quality Changes in Formalin Treated Rohu Fish (Labeo rohita, Hamilton) During Ice Storage Condition. Asian J. Agric. Sci., 2(4): 158-163. 